\title{
Spatio-temporal Assessment of Land-based Pollutants in Water Resources: Yalova, Turkey
}

\section{Oylum Gökkurt Bakia}

Department of Environmental Engineering, Faculty of Engineering and Architecture, Sinop University, 57000 Sinop, Turkey

\begin{tabular}{l|l}
\hline A R T I C L E I N F O & A B S T R A C T \\
\hline Research Article & $\begin{array}{l}\text { The study investigated the water quality characteristics of the spring waters, creeks and lakes in } \\
\text { Yalova Province, Turkey. The 12-month study was carried out in 2005 and the same study was } \\
\text { repeated in the same stations in 2008. Water samples were collected from 9 stations on a monthly } \\
\text { basis. For the determination of the water quality, dissolved oxygen, pH, temperature, ammonium } \\
\text { nitrogen, nitrite and nitrate nitrogen, potassium, total copper, chlorine, sulphate, iron, phosphate, } \\
\text { zinc and sulfide analyses were performed. The water quality parameters of the spring waters, } \\
\text { creeks and lakes were determined with respect to months and years. The stations that are known } \\
\text { to receive wastewater and solid waste inputs were revealed to have high concentrations of water } \\
\text { pellution-indicating parameters. }\end{array}$
\end{tabular}

Keywords:

Land-based pollution

Water pollution

Sustainable water management

Yalova

Surface water

Türk Tarım - Gıda Bilim ve Teknoloji Dergisi 7(3): 417-425, 2019

\section{Karakökenli Kirleticilerin Su Kaynaklarında Zamansal ve Mekansal Değerlendirmesi: Yalova, Türkiye}

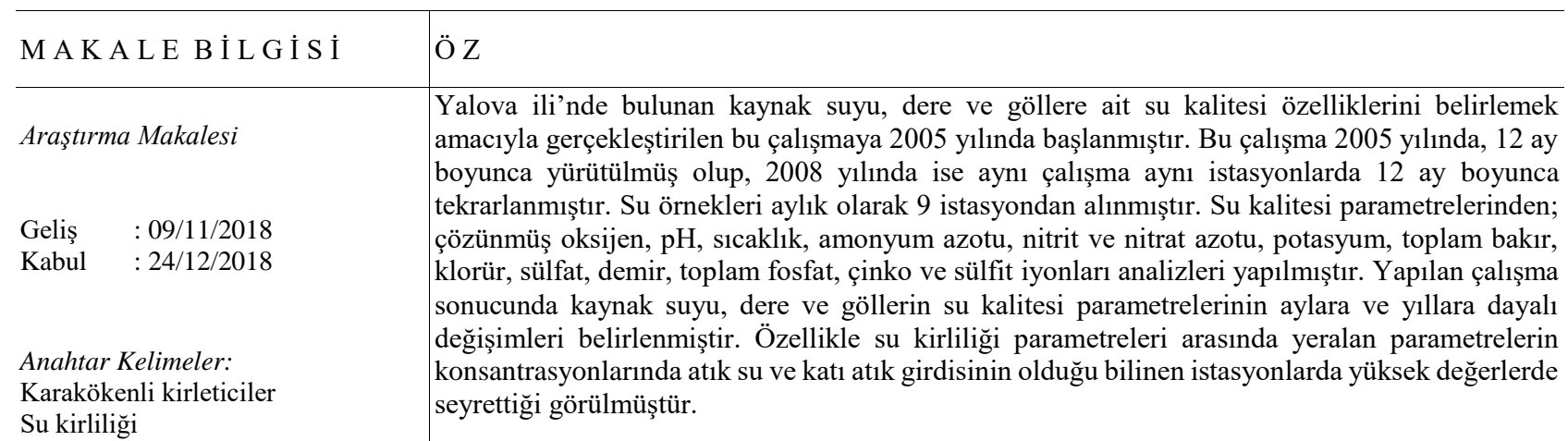

Sürdürülebilir su yönetimi

Yalova

Yüzey suları 


\section{Introduction}

Surface waters should be protected for their sustainable use considering their recreational properties, value as a source of income in terms of water products, their potential for tourism and other numerous important qualities. The desire of human beings to escape from their exhaustive urban lives at least for a little while resulted in an increased demand for sea and lake coasts, which offer beautiful natural scenery. Benefits of fresh air, sun and water to human health have also attracted attention to coasts (Kuntalp, 2014; Gokkurt Baki, 2015). All environmental protection studies and studies involving the prevention of environmental issues should start with understanding and recognizing the current issues.

The surface water quality is a major concern worldwide, as water use is threatened by the generalized contamination due to human activities. Wastewater has a constantly changing structure, which is a result of various human activities. When discharged into receiving environments such as rivers, lakes and seas, wastewaters significantly alter the physicochemical and biological structure of the water and cause significant changes in its bottom structure (Ünlü et al., 2008). The surface water has suffered from extensive pollution over the last few years due to the uncontrolled fishing, unrestricted shipping, mineral exploitation, dumping of toxic wastes, discharge of domestic wastes from coastal cities and pollutants carried by rivers (Bakan and Arıman, 2004; Mee, 1992). This contamination concerns sediments as well as chemicals and microbiological components originationg from industrial, municipal or agricultural point and nonpoint sources of pollution. Generally, intensification of agriculture in the last decades has been singled out as the most important non-point source of water pollution. This mainly concerns nutrients, nitrogen and phosphorus, which are transported from fertilized agricultural lands to surface waters via runoff and erosion and accelerate the eutrophication process (Bakan et al., 2010). The serious degradation of waters can be explained by a variety of factors ranging from high pollution loads from the rivers that discharge into the sea to improper policies and inadequate management practices. Among the most serious problems is the high level of eutrophication by nutrients from land-based sources (Bakan and Büyükgüngör, 2000).

However, in the control of pollution types, the control of diffuse pollution is the most challenging. This is why disease prevention and environmental protection require intensive monitoring and accurate assessment of water quality in rivers. In environmental management and research, water quality data have become imperative to assess the water quality status; to study the controlling processes of water pollution; to define and apply environmental objectives; to restore or improve water quality; to assess the effects of best management practices in a watershed and to calibrate hydraulics and water quality models (Quilbe et al., 2006; Bakan et al., 2010).

The surface water quality in a region is largely determined by the natural processes, anthropogenic influences, urban, industrial and agricultural activities and increasing exploitation of water resources (Singh et al. 2005; Carpenter et al., 1998; Jarvie et al., 1998). The atmosphere and streams are the main carriers of pollution in lakes. There is a constant transaction between lakes and the lands surrounding the lakes as lakes receive the drainage waters from considerably large pieces of land. Surface and underground flows enter and exit the lakes. These flows bring along physical, chemical and biological components, organic substances, residues and various other substances (Ünlü et al., 2008).

Unlike other water resources, lakes are constantly the receiving environments and thus, primarily affected by environmental pollution. The degradation of the quality of surface waters adds to the importance of the studies about nutrient dynamics and water quality (Mutlu and Aydın Uncumusaoğlu, 2016; Kurnaz et. al., 2016; Mutlu and Kurnaz, 2017). Therefore, there are various studies focusing on nutrient dynamics and water quality (Tepe and Mutlu, 2004; Mutlu et. al., 2016; Mutlu et. al., 2018).

The decrease in the quality of the surface water quality in a region is attributed to the increase in greenhouse activities especially in the late 90s. This problem has become very serious especially in surface waters with a static structure (e.g. lakes). The study was carried out to offer recommendations for the sustainable management of the water resources of the spring waters, streams and lakes of Yalova, Turkey, reveal the properties of the current and potential sources of pollution and determine the seasonal changes in the water resources. The determination of the types of the pollutants in the specified stations was carried out through seasonal sample collections and observations. The state of the current hot spots was revealed through the examination of the samples collected from the stations.

\section{Material and Methods}

\section{Study Area and Sampling Stations}

In the study, first, the institutions that previously carried out studies in the region were consulted and the stations were determined by paying particular attention to the locations of the terrestrial pollution sources. In the determination of the stations, sources that best represent the area and feed each other were selected. Seasonal sample collections and observations were conducted to identify the type of the pollution sources in the stations. The samples collected from the stations were examined to reveal the state of the current hot spots. Figure 1 and Table 1 show the locations and coordinates of the stations, respectively.

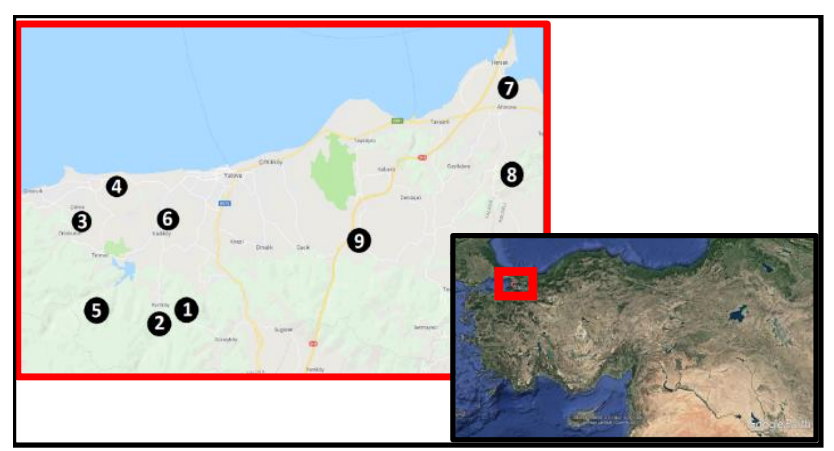

Figure 1 The study area and the stations 
Table 1 Information about stations

\begin{tabular}{|c|c|c|}
\hline Station no & Station name & Coordinates \\
\hline 1 & Kurtköy spring water & $40^{\circ} 34^{\prime} 11,43^{\prime \prime} \mathrm{K}-29^{\circ} 13^{\prime} 48,99^{\prime \prime} \mathrm{D}$ \\
\hline 2 & Kurtköy stream & $40^{\circ} 33^{\prime} 33,97^{\prime \prime} \mathrm{K}-29^{\circ} 13^{\prime} 05,24^{\prime \prime} \mathrm{D}$ \\
\hline 3 & Ortaburun irrigation dam lake & $40^{\circ} 36^{\prime} 39,43^{\prime \prime} \mathrm{K}-29^{\circ} 08^{\prime} 10,23^{\prime \prime} \mathrm{D}$ \\
\hline 4 & Koruköy değirmen köprü & $40^{\circ} 38^{\prime} 51,17^{\prime \prime} \mathrm{K}-29^{\circ} 10^{\prime} 52,72^{\prime \prime} \mathrm{D}$ \\
\hline 5 & Üvezpınar nacaklı stream & $40^{\circ} 34^{\prime} 27,26^{\prime \prime} \mathrm{K}-29^{\circ} 08^{\prime} 53,29^{\prime \prime} \mathrm{D}$ \\
\hline 6 & Üvezpınar şaban stream & $40^{\circ} 37^{\prime} 36,18^{\prime \prime} \mathrm{K}-29^{\circ} 13^{\prime} 33,17^{\prime \prime D}$ \\
\hline 7 & Hersek Lake & $40^{\circ} 43^{\prime} 00,17^{\prime \prime} \mathrm{K}-29^{\circ} 30^{\prime} 27,49^{\prime \prime} \mathrm{D}$ \\
\hline 8 & Altınova ayazma stream & $40^{\circ} 40^{\prime} 39,74^{\prime \prime} \mathrm{K}-29^{\circ} 30^{\prime} 22,69^{\prime \prime} \mathrm{D}$ \\
\hline 9 & Kilıç stream & $40^{\circ} 37^{\prime} 04,06^{\prime \prime} \mathrm{K}-29^{\circ} 23^{\prime} 17,31^{\prime \prime} \mathrm{D}$ \\
\hline
\end{tabular}

In the surface waters within the Yalova provincial borders, the highest flow rates are observed in February and March. Flow rates are considerably low in summer, but water is always present in stream beds. The flow continues in summer due to the forest cover in the feeding areas and various sources. The lowest flow rate is observed in late summer. The first two stations were established as the clean stations. The Kurtköy spring water was the first station and is an underground spring water. It is located in the Kurtköy district close to the city centre. There are no domestic or agricultural pollutants near the spring water. Kurtköy Stream was selected as the second station and rises in the northern slopes of Taşpınar and Beşpınar Hills located within the provincial boarders of Gemlik County. It is fed by multiple surrounding streamlets and partially under the risk of domestic and agricultural pollution. The third station was Ortaburun irrigation dam lake and built by the State Hydraulic Works for agricultural irrigation and had a capacity of 1.900 thousand $\mathrm{m}^{3}$. There are no domestic or agricultural pollutants near the irrigation dam lake. The fourth station was Koru Değirmen Köprü and is composed of the streamlets rising in the backs of Hafiz Yolu Hill and Çakıllı Hill and passes through Ortaburun Village, waters a portion of the soils of Çalıca Village and, then, empties into the sea at Koru Plain. The greenhouses of the horticulture sector of the region, which is an important source of income for the region, is located on this plain. The fourth station is under the risk of agricultural pollution. Nacakl1 Stream and Şaban Stream were the fifth and sixth stations and are fed by multiple surrounding streamlets. The stream merges with Ferhat Stream rising from the west and continues its flow northward, then, connects with Şeftali Stream and Havuz Stream and merges with İsmail Stream rising in the hot springs located at Sellimandira and is referred to as Sellimandira Stream from there forward. From this point on, its bed widens and the stream waters the fields of Yenimahalle, Kadıköy and Samanlı Villages and State Hatchery. At Dereağzı, it is referred to as Samanlı Stream and empties into the sea. Samanl Stream is the widest and longest stream and carries the highest amount of water. In summer, the region serves as a resort for enthusiasts. It is the main water carrier of the Gökçe Dam, which is the drinking water supply of Yalova, and there are no domestic and agricultural pollutants. Lake Hersek was selected as the seventh station. It is a lagoon lake within the borders of Altınova County of Yalova and located on the east of the Sea of Marmara and connects with the Gulf of İzmit. Its average depth is $5 \mathrm{~m}$ and surface area is 150 ha. The lake has a diverse flora and fauna. It is a home to various bird species and serves as a transit point for migratory birds. Because of its importance in aquatic plants and fish and bird species, it was registered as a Grade 1 Natural Protected Area in 2014 by the decision of the Bursa Regional Cultural and Natural Heritage Preservation Board. However, the lake and its surroundings are damaged by the unauthorized solid waste disposal especially after the earthquake disaster in 1999. In addition, the construction of a shipyard site by filling the shoreline on the northeast of Lake Hersek had a negative impact on the lake. There are agricultural lakes near the lake and the potential mixing of the irrigation waters with the lake can also be a triggering factor for the pollution of the lake. Moreover, the İzmir-İstanbul highway begins at the İzmit Gulf Bridge at the north of the lake and skirts the lake. The lake is under a high risk of domestic and agricultural pollution. The eighth station was the Ayazma StreamYalakdere, which forms the Hersek Plain and empties into the Sea of Marmara. Yalakdere is fed by Derbent Stream, Sulu Stream and Akçat Stream. It is one of the most important streams of Yalova and partially under the risk of domestic and agricultural pollution. The ninth station was Kılıç Stream, which empties into the sea at Çatalburun near Taşköprü. The stream dries up during July and August. It is partially under the risk of domestic and agricultural pollution.

\section{Method}

The samples were collected from the stations and analysed monthly for the comparison of the values obtained in 2005 and 2008. The parameters used in the analysis of the water were water temperature $\left({ }^{\circ} \mathrm{C}\right)$, dissolved oxygen (DO), $\mathrm{pH}$, ammonium nitrogen $\left(\mathrm{NH}_{4}{ }^{+}-\right.$ $\mathrm{N})$, nitrite nitrogen $\left(\mathrm{NO}_{2}{ }^{-}-\mathrm{N}\right)$, nitrate nitrogen $\left(\mathrm{NO}_{3}{ }^{-}-\mathrm{N}\right)$, potassium $(\mathrm{K})$, total copper $(\mathrm{Cu})$, chloride ion $\left(\mathrm{Cl}^{-}\right)$, sulfate ion $\left(\mathrm{SO}_{4}^{-2}\right)$, iron $(\mathrm{Fe})$, total phosphorus $\left(\mathrm{PO}_{4}{ }^{-3}\right)$, zinc $(\mathrm{Zn})$ and sulfite ion $\left(\mathrm{SO}_{3}^{-2}\right)$. Temperature and $\mathrm{pH}$ were determined by in-situ measurements with a WTW multiparameter meter. The analyses of other parameters (dissolved oxygen, ammonium, nitrite, nitrate, potassium, total copper, chlorine, sulphate, iron, phosphate, zinc and sulphide) were performed using the Palintest 7100 portable photometer device and reagent.

The volume of the water samples allowed their easy transportation to the laboratory. It is advisable to pay particular attention to preserve the composition of the samples during their transportation. During the sample collection, the samples representing the body of water in a 
realistic way under the current conditions and did not deteriorate before reaching the laboratory were selected. Attention was given to thoroughly washing the sample cups. In addition, the samples were collected in a way that allows shaking the sample container 2-3 times (Şengül and Türkman, 1998). For each sample, a label was added on the sample vial or container with the necessary explanations.

For water analysis, minimum 2 litters of sample were collected from each station. Changes due to organism growth can be greatly delayed by storing the samples under dark and cold conditions. Thus, the samples that can be kept for a certain amount of time were stored in the cupboards at $-20^{\circ} \mathrm{C}$. Various sample protection techniques were applied if the time elapsed between sample collection and analysis was too high and can cause physical or chemical changes in the sample.

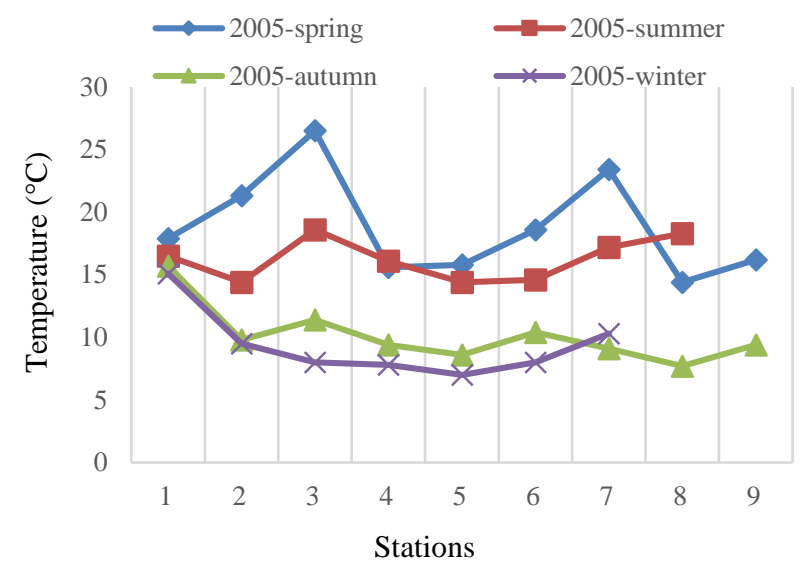

\section{Results and Discussion}

The primary aim of the study was the identification of the pollution factors in the specified surface waters. The determination of the type of pollutants in the designated stations was carried out with monthly sample collections and observations. The status of the existing hot spots was revealed by examining the samples.

Dissolved oxygen (DO) concentration is an equivalent parameter to the self-renewability property of a surface water.According to the physicochemical analysis performed for the nine stations selected in the research area, Station No. 6 had the highest dissolved oxygen concentration in 2005 with a dissolved oxygen concentration of $11.87 \mathrm{mg} .1^{-1}$ (Figure 2). In 2008, with $13.45 \mathrm{mg} . \mathrm{l}^{-1}$, the highest dissolved oxgen concentration was determined in Station No. 1.

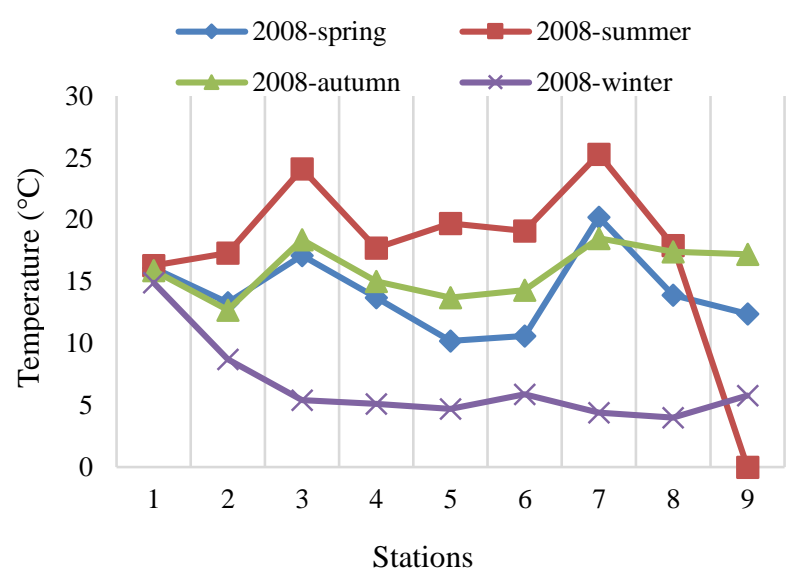

Figure 2 Seasonal change of water temperature in 2005-2008 compared to stations

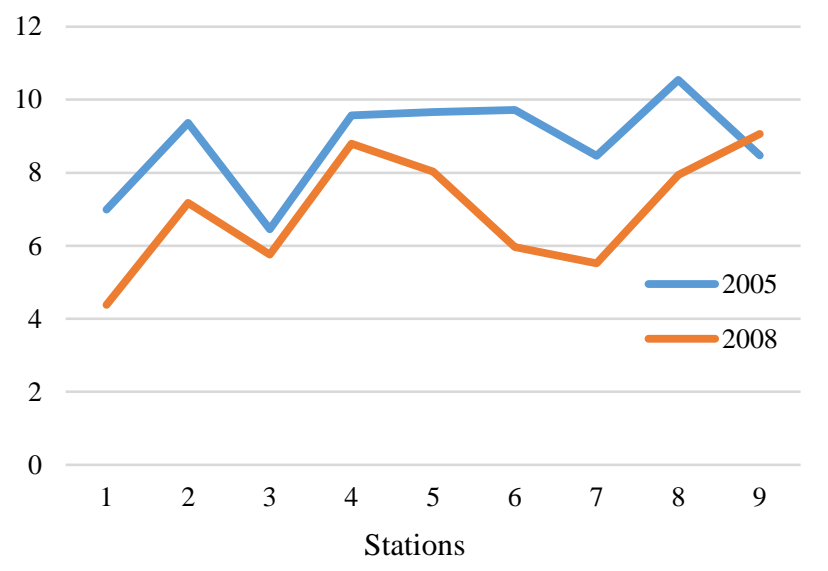

(a)

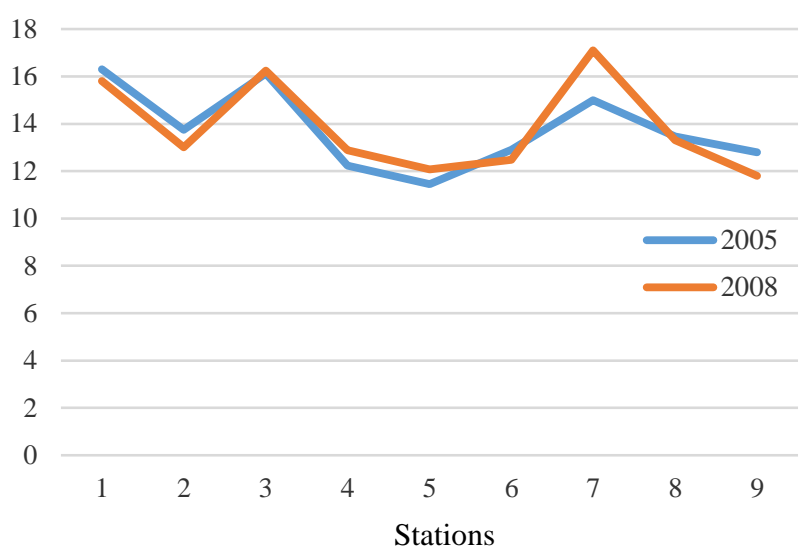

(b)

Figure 3 Average (a) dissolved oxygen and (b) temperature values for the years 2005-2008 according to the stations

According to the monthly evaluations of the stations in 2005, the highest temperature value was $26.5^{\circ} \mathrm{C}$ and determined in Station No. 2 in spring, while lowest temperature value was $7^{\circ} \mathrm{C}$ and determined in Station No. 5 in winter (Figure 3). In 2008, the highest temperature was $25.3^{\circ} \mathrm{C}$ and determined in summer in Station No 7 while the lowest temperature value was $4^{\circ} \mathrm{C}$ and determined in Station No. 8 in winter. The data revealed that there was no thermal pollution and the changes in temperature change was due to seasonal changes (Figure 2).

According to the evaluation of the stations in terms of $\mathrm{pH}$, with a $\mathrm{pH}$ of $8.72 \mathrm{mg} . \mathrm{l}^{-1}$, Station No. 3 had the highest $\mathrm{pH}$ value in spring of 2005 . In the same year, the lowest $\mathrm{pH}$ value was determined to be $6.99 \mathrm{mg} . \mathrm{l}^{-1}$ in the same station in winter (Figure 4). For 2008, the highest $\mathrm{pH}$ value was $8.92 \mathrm{mg} . \mathrm{l}^{-1}$ and determined in Station No. 2 in spring, followed by Station No 7 with a $\mathrm{pH}$ value of $7.69 \mathrm{mg} . \mathrm{l}^{-1}$ in winter. 


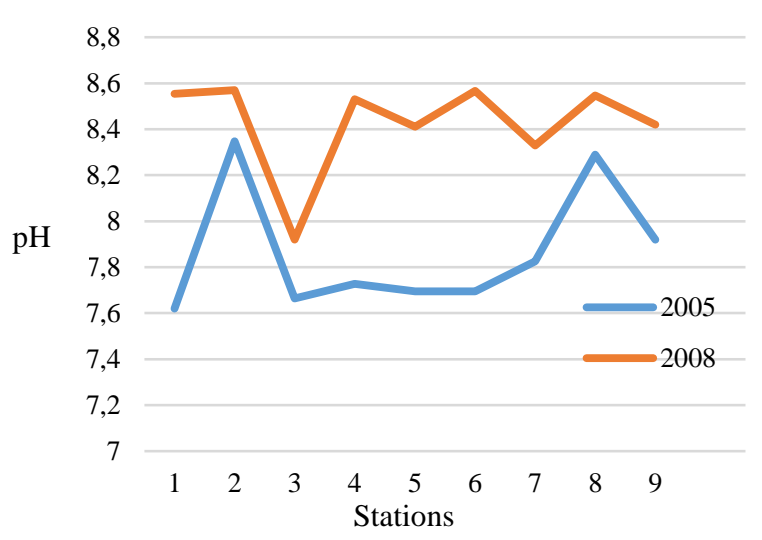

Figure 4 Change in average $\mathrm{pH}$ value of 2005-2008

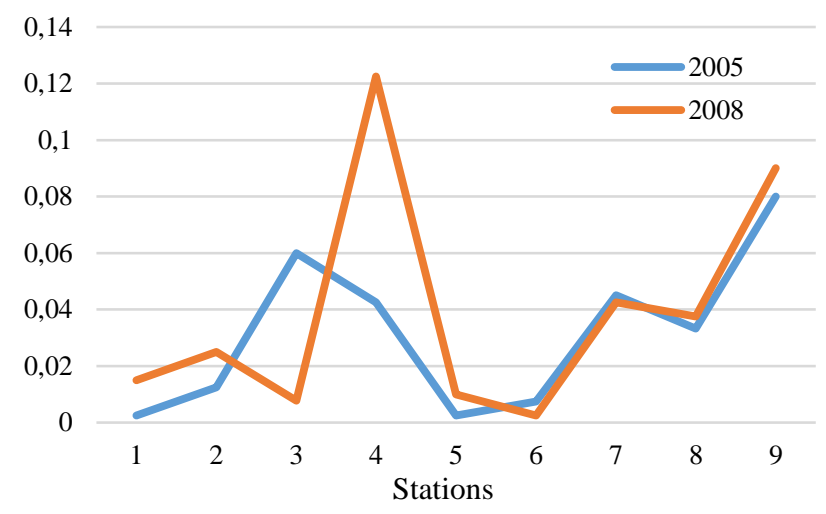

(a)

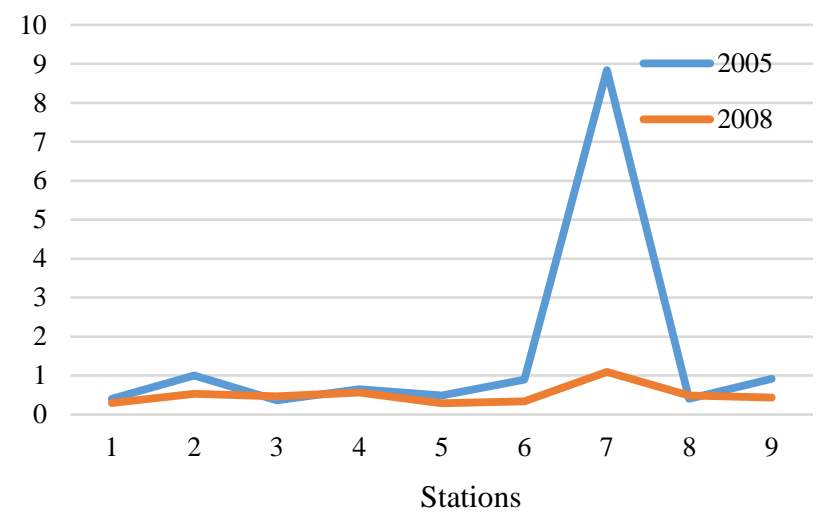

(b)

Figure 5 Average (a) nitrite-N (b) nitrate-N values for the years 2005-2008 according to the stations

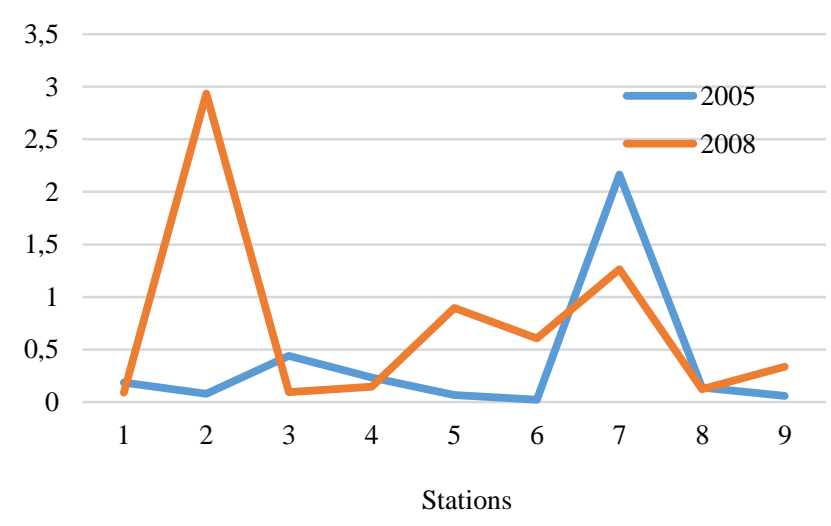

Figure 6 Average ammonium nitrogen values for the years 2005-2008
The overall evaluation of the monthly nitrite nitrogen concentrations in the stations showed that Station No. 2 had the highest nitrite nitrogen concentration in 2005, followed by Sation No 9 (Figure 5). The lowest nitrite nitrogen value was $0.01 \mathrm{mg} . \mathrm{l}^{-1}$ and determined in spring in Stations No. 6 , 7 and 8. In 2008, with $0.15 \mathrm{mg} . \mathrm{l}^{-1}$, the highest nitrite concentration was determined in Station No. 4 and recorded in summer, followed by Station No. 9 with 0.13 mg. $l^{-1}$ in autumn.

According to the monthly nitrate nitrogen values, in 2005, Station No. 7 had the highest value with $7.18 \mathrm{mg} . \mathrm{l}^{-1}$ in winter, followed by, again, Station No.7 with $11.6 \mathrm{mg} . \mathrm{l}^{-1}$ in autumn (Figure 5). The lowest nitrate nitrogen value was $0.02 \mathrm{mg} . \mathrm{l}^{-1}$ and determined in Station No. 8 in autumn. In 2008 , the highest nitrate concentration was $1.84 \mathrm{mg} . \mathrm{l}^{-1}$ and recorded in autumn in Station No. 7, followed by $1.1 \mathrm{mg} . \mathrm{l}^{-}$ ${ }^{1}$ in Station No 7 in summer.

Ammonium compounds are present at very low levels in clean waters. Usually it should be $1 \mathrm{mg} .1-1$ or less. In 2005, ammonium nitrogen was only above this value at station 7. In 2008, it is observed that this value has reached the values that will affect the water quality, especially in the stations where agricultural activities (such as greenhouses) have increased (Figure 6). The highest ammonium nitrogen was $4.49 \mathrm{mg} . \mathrm{l}^{-1}$ and determined in Station No. 7 in winter. This parameter was determined as $2.64 \mathrm{mg} .1-1$ at the same station and in winter. In 2008, the highest value was $5.6 \mathrm{mg} . \mathrm{l}^{-1}$ and determined in Station No. 2 , followed by the same station with $2.55 \mathrm{mg} . \mathrm{l}^{-1}$ in summer.

According to the evalution of monthly potassium levels, in 2005, the highest potassium level was $428.2 \mathrm{mg} \cdot \mathrm{l}^{-1}$ in summer at Station No 7 (Figure 7), followed by the same station with $344.4 \mathrm{mg} . \mathrm{l}^{-1}$ in winter. The lowest potassium value was $0.9 \mathrm{mg} . \mathrm{l}^{-1}$ and determined in Station No. 2 in summer. In 2008, with $266.4 \mathrm{mg} . \mathrm{l}^{-1}$, the highest value was determined in Station No. 7 followed by the same station with $200 \mathrm{mg} . \mathrm{l}^{-1}$ in summer. Potassium is not only an indicator of inland surface water quality (e.g. chloride) but also an indicator of drinking water quality. According to the Turkish Standards Institute (TSE), potassium levels of drinking waters should not exceed $12 \mathrm{mg} \cdot \mathrm{l}^{-1}$. The potassium level of Station No. 5, a drinking water supply and therefore an important station for determining the quality of drinking water, is below this threshold.

In our study, when the total copper changes between months, the highest value in the samples in 2005 was determined as $0.55 \mathrm{mg} . \mathrm{l}^{-1}$ in the autumn 7 , and $0.54 \mathrm{mg} . \mathrm{l}^{-1}$ in the autumn and 6 in the autumn. (Figure 8). The lowest copper concentration value was determined as $0,02 \mathrm{mg} . \mathrm{l}^{-1}$ in spring and 5 station. In 2008, the highest value was recorded as $2.2 \mathrm{mg} . \mathrm{l}^{-1}$ at station 7 in winter. This is followed by $0,18 \mathrm{mg} \cdot \mathrm{l}^{-1}$ and the autumn 4 station.

When the general evaluation of the iron concentration in the research stations was examined, the highest value in the samples in 2005 was determined as $10,86 \mathrm{mg} . \mathrm{l}^{-1}$ in the winter 7. This value is followed by the No. 3 station in the spring with $10.2 \mathrm{mg} . \mathrm{l}^{-1}$ (Figure 8). The lowest iron value was determined as $0.1 \mathrm{mg} .1^{-1}$ in spring and summer seasons. In 2008, the highest value was recorded as 8 mg. $\mathrm{l}^{-1}$ in stations 4 and 5 in winter. This is followed by $4 \mathrm{mg} \cdot \mathrm{l}^{-1}$ and 4 stations in autumn. 


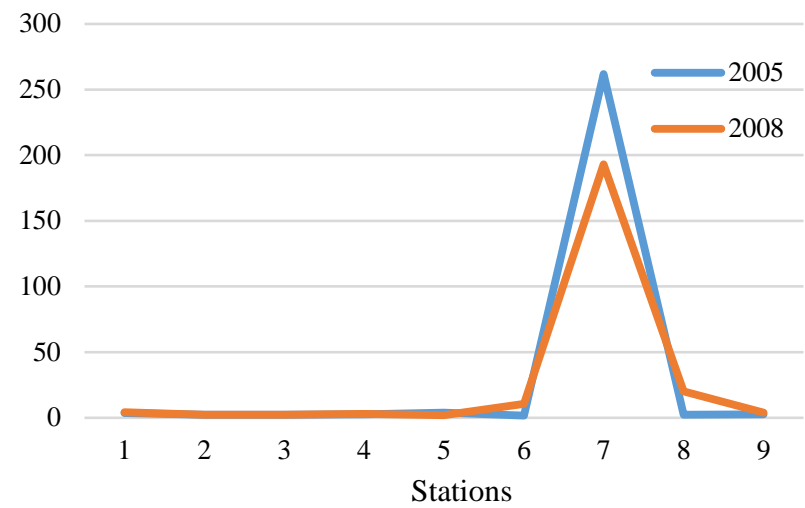

Figure 7 The change in the value of potassium in the years 2005-2008 according to the stations

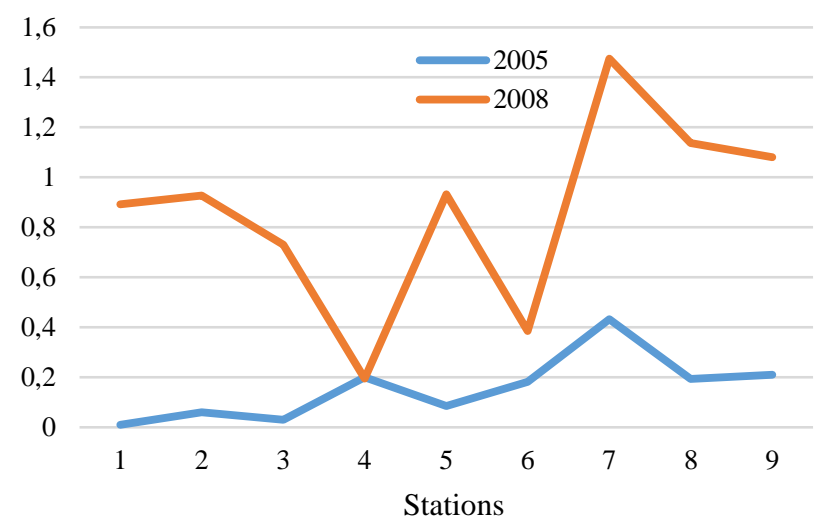

(a)

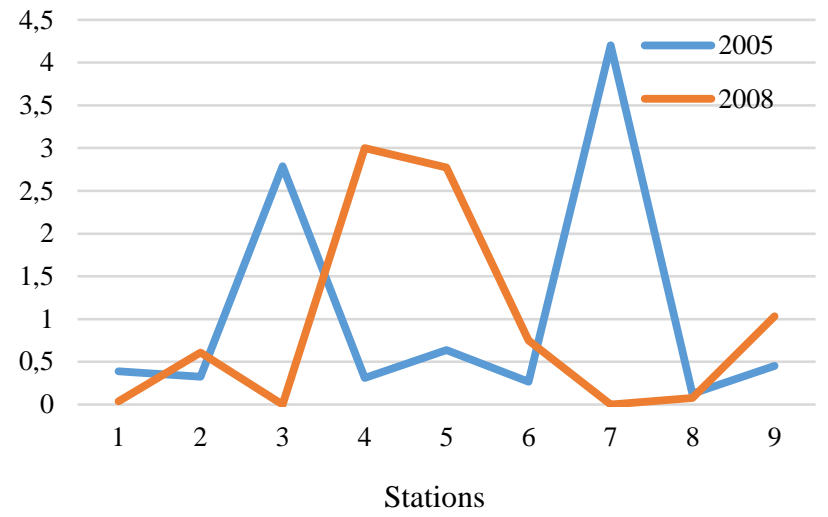

(b)

Figure 8 Stations according to the years 2005-2008 (a) total copper and (b) change in the value of iron

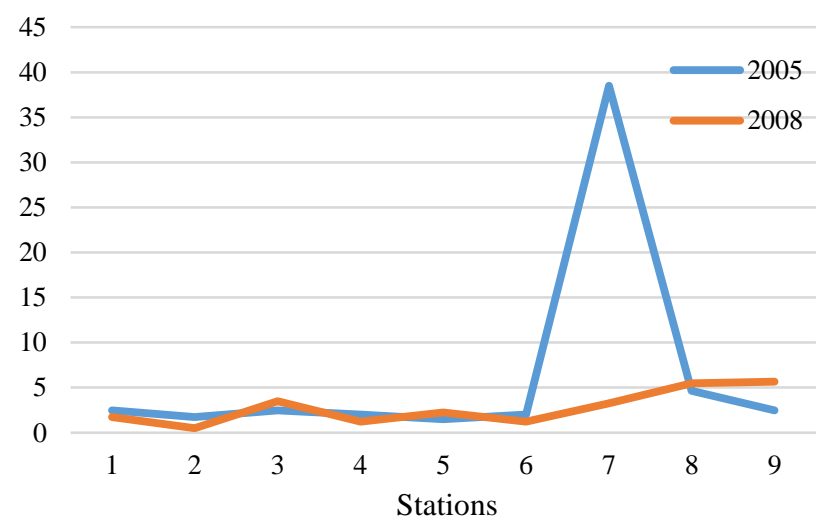

Figure 9 Changes in the chloride ion value in 2005-2008 with respect to the stations
Chlorides are commonly found in nature as $\mathrm{Na}$-salts $(\mathrm{NaCl}), \mathrm{K}$-salts $(\mathrm{KCI})$ and Ca-salts $(\mathrm{CaCl})$. Their solubility increases in hot water (WHO, 2001; Boysan, 2001). High chloride content indicates high salinity and, thus, high electrical conductivity. The amount of chloride ions is an indicator of healthy water. Chloride is an important data for inter-continental groundwaters and a substantially important parameter for drinkable water. In the study, the chloride ion concentration, especially in Station No 5, which is the drinkable water supply of the city, was determined to be considerably below the water quality limits. According to the data obtained in the study, the highest chloride ion value determined in the sampling that was carried out in 2005 was $84 \mathrm{mg} .1^{-1}$ and obtained from Station No. 7 in winter, followed by, again, Station No 7 in autumn with $58 \mathrm{mg} .1-1$ (Figure 9). With $1 \mathrm{mg} . \mathrm{l}^{-1}$, the lowest chloride ion value was obtained in all seasons of 2005. In 2008, with $11 \mathrm{mg} . \mathrm{l}^{-1}$, the highest chloride ion concentration was obtained from Station No 9 and recorded in autumn, followed by Station No 8 with a chloride ion concentration of $8 \mathrm{mg} . \mathrm{l}^{-1}$ in spring. The results indicated that the values were not at levels that can negatively affect the water quality according to the Water Pollution Control Regulation.

Considering the changes in the months of 2005, the highest value was determined in the spring with $2860 \mathrm{mg} \cdot \mathrm{l}^{-1}$ in Station No. 7. This value was followed by the same station in autumn with $1848 \mathrm{mg} . \mathrm{l}^{-1}$ (Figure 10). The lowest sulfate ion value was determined to be $1 \mathrm{mg} . \mathrm{l}^{-1}$ in spring and summer, in Station No. 3 and No. 5. In 2008, the concentration of sulphate ion in the Station No. 7 was 880 mg. $l^{-1}$ and the value was obtained in the summer. This value was followed by Station No. 7 with $270 \mathrm{mg} . \mathrm{l}^{-1}$ station.

In a general evaluation of sulphide ion in terms of months, the highest value was determined to be $2688 \mathrm{mg} . \mathrm{l}^{-1}$ at Station No. 7 station in the winter. This value was followed Station No. 7 with $1221 \mathrm{mg} . \mathrm{l}^{-1}$ in autumn (Figure 10). The lowest sulfide ion value was determined to be $10 \mathrm{mg} .1^{-1}$ in the spring, summer and winter. In 2008, the highest value was determined to be $26 \mathrm{mg} . \mathrm{l}^{-1}$ in Station No. 3 and in spring. This value was $22 \mathrm{mg} . \mathrm{l}^{-1}$ followed by the Station No. 3 in summer.

In an aquatic ecosystem, phosphorus is a growthlimiting nutrient and therefore, functions as a key element for living organisms. The overall examination of the total phosphorus levels in the stations across months showed that in the samplings in 2005, Station No. 7 had the highest phosphorus level in winter with $600 \mathrm{mg} \cdot \mathrm{l}^{-1}$, followed by, again, Station No. 7 in autumn with $52 \mathrm{mg}^{-1^{-1}}$ (Figure 11). With $1 \mathrm{mg} . \mathrm{l}^{-1}$, the lowest phosphorus value was determined in autumn and summer in Stations 9, 4, 3, 2 and 1. In 2008, the highest value was $12 \mathrm{mg} .1^{-1}$ and obtained in Station No. 1 in summer, followed by Station No. 5 in spring with 11 mg. $1^{-1}$.

In the stations investigated in the study, evaluating thechanges in zinc levels between the months, the highest value in 2005 was determined to be $0.75 \mathrm{mg} . \mathrm{l}^{-1}$ in autumn at Station No. 7. This value was followed by Station No. 3 with 0.57 mg. $1^{-1}$ in spring (Figure 12). The lowest zinc ion value was found to be $0.01 \mathrm{mg} . \mathrm{l}^{-1}$ in spring, in Stations 1 , 4 and 5. In 2008, the highest value was recorded as 0.44 mg..$^{-1}$ at Station No. 7 station in summer. This value was followed by Station No.7 with $0.34 \mathrm{mg} . \mathrm{l}^{-1}$ in spring. 


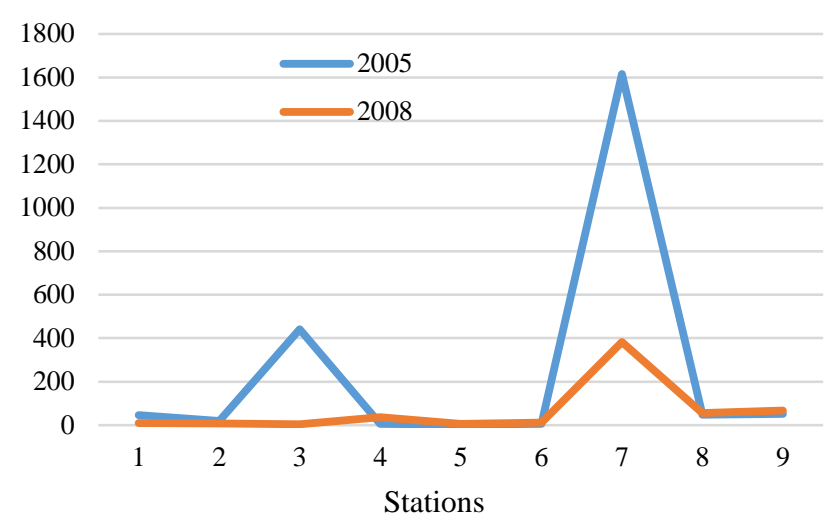

(a)

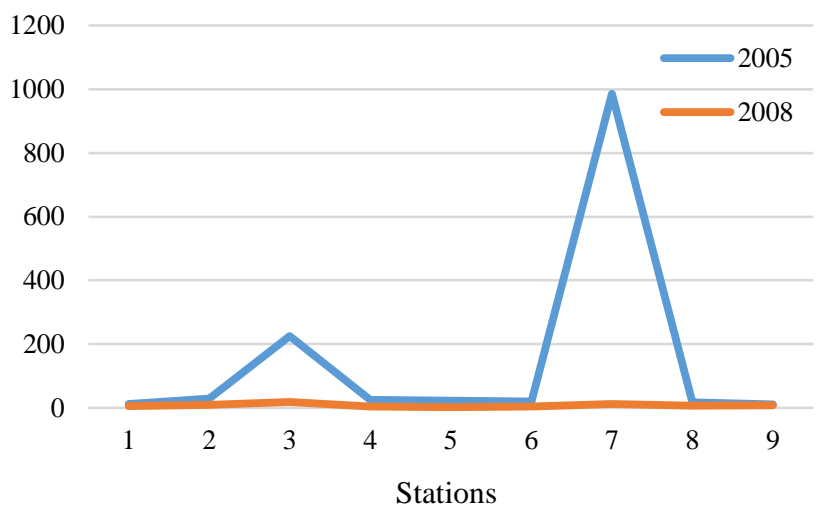

(b)

Figure 10 The change in the values of (a) sulphate (b) sulfite ions in the years 2005-2008

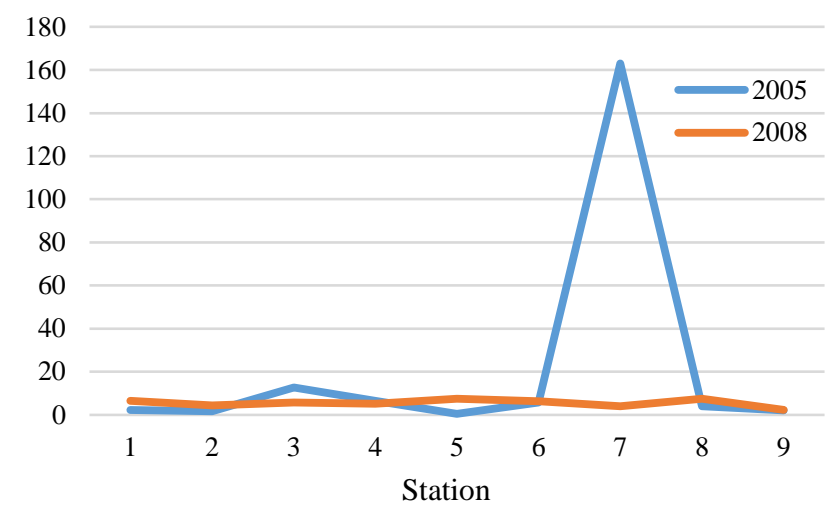

Figure 11 Changes in the total phosphorus value in 20052008 with respect to the stations

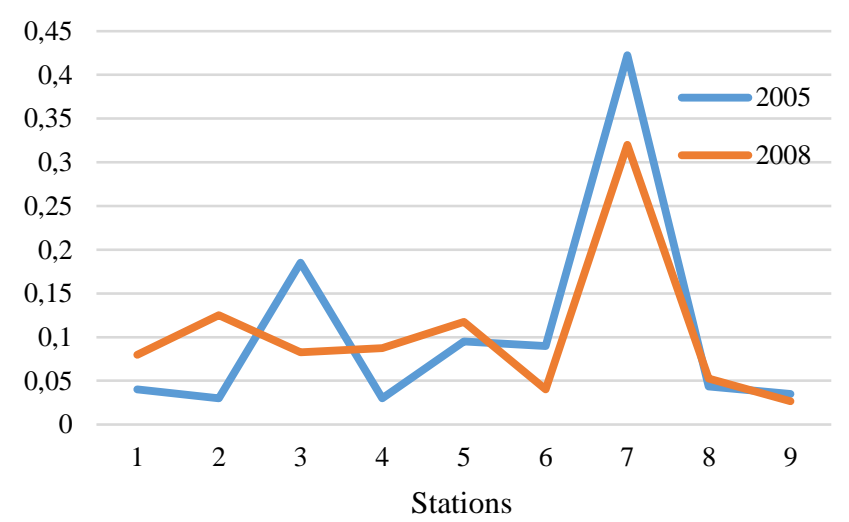

Figure 12 Change in the value of zinc between the years 2005-2008 according to the stations
The results obtained in the study were discussed with reference to the "Water Pollution Control Regulation" (Anonymous, 2004) that was prepared based on Article 9 of Environmental Law No. 2872. In light of this purpose, certain parameters were compared with respect to Table 1 of the regulation showing the Quality Criteria Based on the Classes of Inter-continental Water Resources. According to the results obtained for dissolved oxygen, Station No. 1 had Class II quality water in summer, autumn and winter. The dissolved oxygen data for 2008 showed that almost all stations had Class II quality water. The comparison of the $\mathrm{pH}$ values with the regulation revealed that Stations 1,3 and 5 had Class III quality water. In the study, the number of stations with potential agricultural pollution was high and especially Station No. 4 and Station No. 7, which was exposed to waste disposal after the earthquake, had ammonium and nitrate nitrogen levels above the limits described in the regulation. In 2005, Station 7 had Class IV quality water in autumn, winter and summer in terms of its sulfate content. In 2008, Station No. 7, again, had Class IV quality water in summer in terms of the same property. The highest zinc level was determined in Station No. 7 in autumn, which is attributable to its exposure to solid wastes. According to the regulation, the station had Class III quality water. The examination of the same parameter for 2008 showed that, with $440 \mu$ gr.1-1, Station No. 7 had the highest zinc level and had Class II quality water in summer. The investigation of the iron concentrations with respect to years, seasons and stations showed that Station No. 7, which was exposed to debris piles, had Class IV quality water in autumn and winter according to the sampling in 2005. According to the regulation, the data is above the threshold of $5000 \mu \mathrm{gr} .1-1$, which indicates Class IV quality water in terms of iron concentration.

The irregular and unplanned housing near the lake should be controlled by abiding by the regulations for coastal protection with meticulous care. The water level of the lake should be preserved, so that ecological balance is not disturbed. In addition, the improvement works in 2008 brought down the iron levels to the limits of the regulation.

\section{Conclusion}

The results showed that Station No. 7 (Lake Hersek) in which domestic waste waters were discharged especially after the earthquake had the highest nitrate nitrogen, ammonium nitrogen, potassium, total copper, chloride ion, sulfate and sulfide ion, iron, zinc and phosphate levels compared with other stations. The station is filled with construction wastes generated by the earthquake in 1999 . Moreover, the connection of Hersek Lagoon with the sea was cut due to the sand accumulation on the shore and the lake became a lake with no point of entry or exit for water. Thus, it turned into a stagnant water body and was determined to have a considerably decreased dissolved oxygen concentration especially in 2008. The degradation of water quality in certain stations reveals the loss of flora and fauna in the region. The lagoon areas that provide a living environment for diverse flora and fauna have important functions in the hydrological and chemical cycles related to the remediation of polluted waters (İleri et al., 2014; Elmac1 et al., 2010; Katip and Karaer, 2011; Lai et al., 2012). In addition, compared with other stations, 
Station 4 (Kuruköy Değirmen Köprü), which exhibits the properties of nonpoint source pollution that is attributable to the agricultural irrigation area, had relatively higher nitrite nitrogen concentration depending on the season.

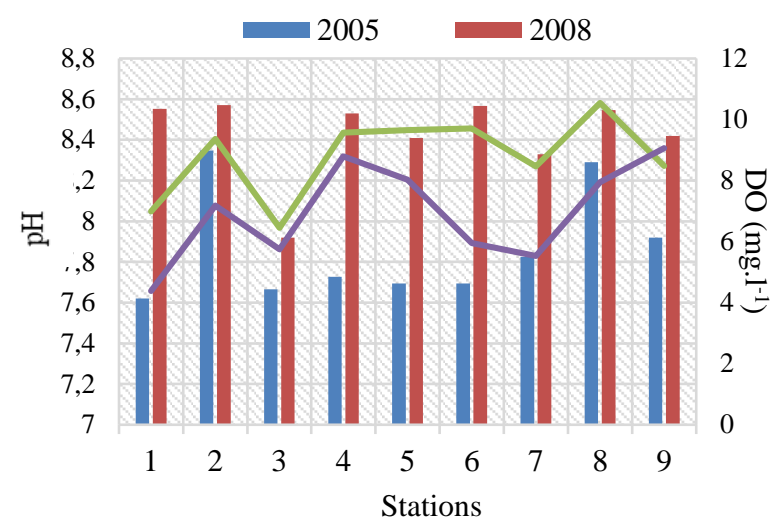

Figure 13 Changes in $\mathrm{pH}$ and dissolved oxygen through the years

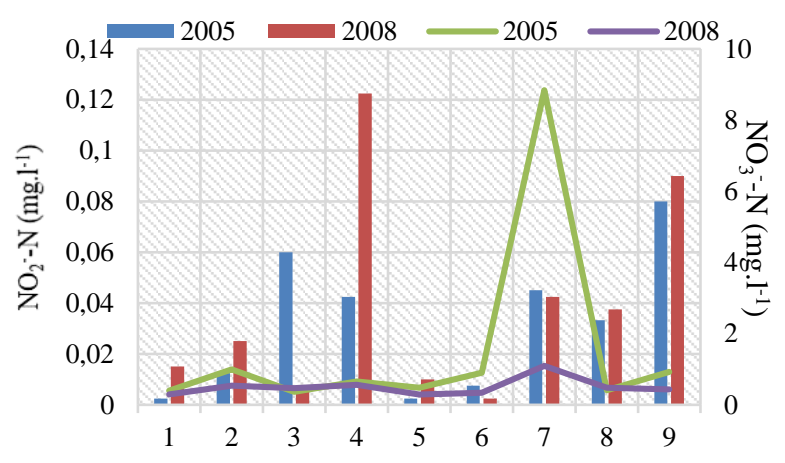

Figure 14 Changes in nitrite nitrogen and nitrate nitrogen through the years

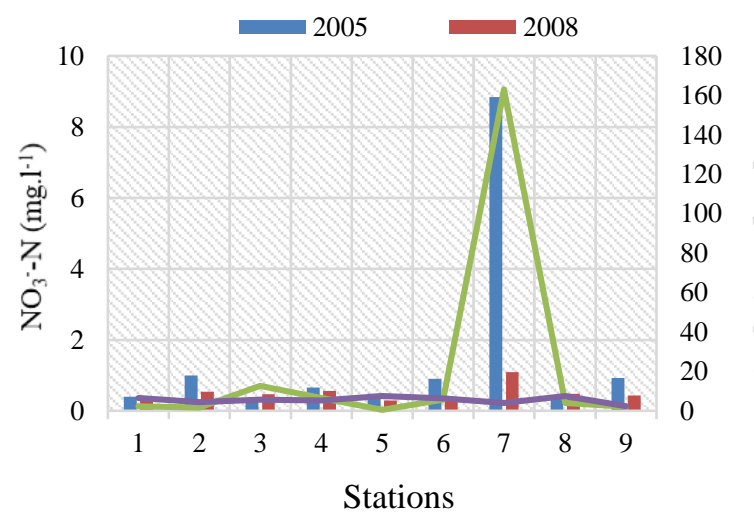

Figure 15. Changes in nitrate nitrogen and total phosphorus through the years

In the study, parameters than can both determine water quality and water pollution were determined. Moreover, the general properties of the stations were also taken into consideration in the determination of the parameters. As one of these parameters, the acidity and alkalinity of the water body can be determined by measuring the $\mathrm{pH}$ of the water body. It has been reported that there is a negative relationship with oxygen and $\mathrm{pH}$, the dissolved carbonate in calcareous regions can lead to $\mathrm{pH}$ levels around 9, increased $\mathrm{pH}$ levels can result in the conversion of the ammonium ions in the media into ammoniac, which has a toxic effect on fish, and thus, the negative effects of the organic substances that are released into the lakes at higher $\mathrm{pH}$ and temperature values are aggravated (Ünlü and Uslu, 1999; Taş, 2006). As seen in Figure 13, the negative relationship was also evident in the results obtained in this study. This was associated with the stagnation of the water bodies and rock structure.

Nitrogenous compounds are known to form mostly due to agricultural activities, especially due to nitrogenous fertilizers, and mix with surface waters in the form of nonpoint source pollution. In the study, Station No. 4, which was determined to have the highest number of agricultural lands in its vicinity, had a higher $\mathrm{NO}_{2}^{-}-\mathrm{N}$ and $\mathrm{NO}_{3}{ }^{-}-\mathrm{N}$ concentration than the other stations (Figure 14). Furthermore, the results showed that the $\mathrm{NO}_{2}^{-}-\mathrm{N}$ and $\mathrm{NO}_{3}{ }^{-}$ -N concentration of Station No. 4 increased between 2005 and 2008, which was attributed to the increased greenhouse activities in the region. Moreover, the presence of nitrite in the station may be an indicator of fecal pollution in addition to the pollution due to nitrogenous fertilizers.

Dissolved phosphate, nitrate and carbonate in water are nutrients for living organisms in aquatic ecosystems. Studies have shown that these dissolved substances had a mole fraction of $\mathrm{C}: \mathrm{N}: \mathrm{P}=106: 16: 1$. Among these substances, phosphorus emerge as a growth-limiting element. Figure 15 shows the changes in total phosphorus and nitrate nitrogen concentrations through the years. According to the Water Pollution Control Regulation, the amount of phosphorus in the lake environments exceeded the limit values for eutrophication (0.005-1.0 mg. $\left.\mathrm{l}^{-1}\right)$ (Anonymous, 2004). This is mainly due to the agricultural wastewaters and domestic wastewaters released by the settlements near the aquatic ecosystem. As seen in Figure 15 , the total phosphorus and nitrate nitrogen concentrations of Station No. 7 were high because of its intense exposure to wastes and the stagnation of the water body due to the wastes, which reached levels that can negatively affect the living organisms in the water body.

In the study, stations 1 and 2 were established as clean stations. In general, depending on the period, increases were observed in the water pollution parameters especially in stations with stagnant water bodies (lake, pond, etc.). Especially the dissolved oxygen levels in the areas that contain domestic wastes or pollution stemming from agricultural areas decreased and compared with the values in 2005, increases in $\mathrm{pH}$, nitrogenous compound and phosphate levels were observed in 2008.

The results revealed that there were significant regional and seasonal changes in the pollution parameters of the stations. For the appropriate utilization of a water resource, it should be periodically monitored. Through the monitoring of water resources, the regions under a higher pressure can be determined, the reasons underlying the elevated pressure on these regions can be identified and control processes for areas under increased pressure can be discussed. Sustainable monitoring of the water resources, developing an effective and sustainable management plan to protect the water quality, administrative studies and coordination at the basin scale and modelling studies to monitor and evaluate the changes in water and, if possible, sediment quality are recommended for the water resources in Yalova. 
Furthermore, quantitative properties of the receiving environments, especially their flow rates, and the purpose of the protection of water quality should be determined to take water pollution control measures. Thus, the pollution loads stemming from the point and non-point sources that affect the quality of the water environment can be determined. Through the determination of the pollution load, technological calculations and control methods for the aquatic environment can be specified. Adopting an economic, administrative, legal and technological approach to the control of water pollution for all surface waters is an absolute necessity for sustainable water management.

\section{Acknowledgements}

The author would like to thank Assoc. Prof. Dr. Birol Baki for the exchange of ideas and sharing his information and experience. This study was presented as an oral presentation with English abstract in II. International Conference on Civil and Environmental Engineering on 08.05.2017-10.05.2017.

\section{References}

Anonim. 2004. Su Kirliliği Kontrolü Yönetmeliği, http://cygm.csb.gov.tr/yonetmelikler-i-440 (accessed date: 02.10.2018)

Bakan G, Büyükgüngör H. 2000. The Black Sea, Marine Pollution Bulletin Vol.41, Nos.1-6, pp.24-43, 2000

Bakan G, Ariman S. 2004. Persistent organochlorine residues in sediments along the coast of mid-Black Se region in Turkey, Marine Pollution Bulletin, 48, 1031-1039

Bakan G, Özkoç H, Tülek S, Cüce H. 2010. Integrated environmental quality assessment of Kizılırmak River and its coastal environment. Turkish Journal of Fisheies and Aquaitc Sciences. 10: 453-462

Boysan F, Şengörür B. 2001. Şişelenmiş içme sularındaki bazı inorganik parametrelerin insan sağlığına etkilerinin araştırılması, SAU Fen Bilimleri Enstitüsü Dergisi, 5. Cilt, 2. Say1

Carpenter SR, Caraco DL, Cornell DL, Howarth RW, Sharpley AN, Smith VH. 1998. Ecol. Appl. 8(1998) 559

Elmacı A, Topaç FO, Teksoy A, Özengin N, Başkaya HS. 2010. Uluabat Gölü fizikokimyasal özelliklerinin yönetmelikler çerçevesinde değerlendirilmesi. Uludağ University Journal of The Faculty of Engineering and Architecture, 15(1), s: 149157.

Gökkurt Baki O, Ergun ON, Bat L. 2015. Sustainable tourism indicators and coastal management plan in the south of the Black Sea, Journal of Coastal Life Medicine 2015; 3(1): 930$936 \mathrm{pp}$.

İleri S, Karaer F, Katip A, Onur S. 2014. Sığ göllerde su kalitesi değerlendirmesi, Uluabat Gölü Örneği, Uludağ Üniversitesi Mühendislik-Mimarlık Fakültesi Dergisi, Cilt 19, Sayı 1

Jarvie HP, Whitton BA, Neal C. 1998. Sci. Total Environ. 20/211 (1998) 79
Katip A, Karaer F. 2011. Uluabat Gölü su kalitesinin Türk mevzuatına ve uluslararası kriterlere göre değerlendirilmesi. Uludağ University Journal of the Faculty of Engineering and Architecture, 16(2), s: 25-34, 2011.

Kuntalp E. 2014. Legal order of the Coasts, pp. 76-79, 2014, (in Turkish with English Abstract) [Online] Availlable: http://dergi.mo.org.tr/ dergiler/4/285/4019.pdf (October 20, 2014)

Kurnaz A, Mutlu E, Aydın Uncumusaoğlu A. 2016. Determination of water quality parameters and heavy metal content in surface water of Çiğdem Pond (Kastamonu/Turkey). Turkish Journal of Agriculture - Food Science and Technology, 4(10): 907-913.

Lai XJ, Huang Q, Jiang JH. 2012. Wetland inundation modeling of Dongting Lake using two dimensional hydrodynamic model on unstructured grids. Procedia Environmental Sciences 13: $1091-1098$.

Mee LD. 1992. The Black Sea in crisis: the need for concerted international action. Ambio 21(4): 278-286.

Mutlu E, Aydın Uncumusaoğlu A. 2016. Physicochemical analysis of water quality of Brook Kuruçay. Turkish Journal of Agriculture - Food Science and Technology, 4(11): 991998.

Mutlu E, Kutlu B, Demir T. 2016. Assesment of Çınarlı Stream (Hafik - Sivas)'s water quality via physico - chemical Methods. Turkish Journal of Agriculture - Food Science and Technology, 4(4): 267-278.

Mutlu E, Kurnaz A. 2017. Determination of seasonal variations of heavy metals and physicochemical parameters in Sakiz Pond (Kastamonu-Turkey). Fresenius Environmental Bulletin, 26(4): 2806-2815.

Mutlu E, Aydın-Uncumusaoğlu A. 2018. Analysis of Spatial and Temporal Water Pollution Patterns in Terzi Pond (Kastamonu / Turkey) by Using Multivariate Statistical Methods, Fresenius Environmental Bulletin, 5(27): 29002912

Singh KP, Malik A, Sinha S. 2005. Water quality assessment and apportionment of pollution sources of Gomti river (India) using multivariate statistical techniques-a case study, Analytica Chimica Acta 538 (2005), 355-374

Şengül F, Türkman A. 1998. Su ve atıksu analizleri, $152 \mathrm{~s}$.

Taş B. 2006. Derbent Baraj Gölü (Samsun) su kalitesinin incelenmesi, Ekoloji 15, 60, 1-6

Tepe Y, Mutlu E. 2004. Hatay Harbiye kaynak suyunun fizikokimyasal özellikleri. Dumlupınar Üniversitesi, Fen Bilimleri Dergisi 6, 77-88

Quilbe R, Rousseau AN, Duchemin M, Paulin A, Gangbazo G, Villeneuve JP. 2006. Selecting a calculation method to estimate sediment and nutrient loads in streams: Application to the Beaurivage River (Quebec, Canada), Journal of Hydrology, 1-16.

Ünlü A, Çoban F, Tunç M S. 2008. Hazar Gölü su kalitesinin fiziksel ve inorganik kimyasal parametreler açısından incelenmesi, Gazi Üniv. Müh. Mim. Fak. Der. Cilt 23, No 1, $119-127$

Ünlü A, Uslu G. 1999. Hazar Gölü'nde su kalitesinin değerlendirilmesi. Ekoloji 8, 32, 7-13.

WHO. 2001. Guidelines for drinking water quality, Vol. 2, pp.100-11O, 145-151, 253-255. 